\title{
Discussion: CHD pile performance: part I - physical modelling
}

John R. Jeffrey MEng, PhD

Geotechnical Engineer, Technip UK Limited, Westhill, UK

Michael J. Brown BEng, PhD

Reader, School of Science and Engineering, University of Dundee, Dundee, UK

Jonathan A. Knappett MA, MEng, PhD

Reader, School of Science \& Engineering, University of Dundee, Dundee, UK

Jonathan D. Ball BSC, CGeol, FGS

Chief Geotechnical Engineer, Roger Bullivant Ltd, Burton Upon Trent, UK

Karlis Caucis MEng

Graduate Engineer, Arup, South Queensferry, UK

Wei Cui BEng

Associate Professor, Research Center of Geotechnical and Structural

Engineering, Shandong University, Jinan, P. R. China
Xiao Zheng BEng

Master Student, Research Center of Geotechnical and Structural Engineering, Shandong University, Jinan, P. R. China

\section{Shi-min Zhang MPhil}

Professor, Department of Civil Engineering, Zhejiang University City College, Hangzhou, P. R. China

Qian-qing Zhang MPhil, PhD

Associate Professor, Research Center of Geotechnical and Structural Engineering, Shandong University, Jinan, China; State Key Laboratory for GeoMechanics and Deep Underground Engineering, China University of Mining and Technology, Xuzhou, P. R. China

\section{Contribution by W. Cui, X. Zheng, S. Zhang and Q. Zhang}

In Equation 1 of Jeffrey et al. (2016), the full flight diameter $D_{\mathrm{f}}$ (see Figure 2) was used to calculate the base area, and the effective diameter $D_{\text {e }}$ (see Figure 2) was selected to determine the shaft area of Equation 2. However, in the numerical analysis of the performance of a continuous helical displacement (CHD) pile (Knappett et al., 2016), the full flight diameter $D_{\mathrm{f}}$ was used to calculate the shaft area, and the core diameter $D_{\mathrm{c}}$ was selected to determine the base area. Could the authors provide the reason why different diameters were chosen to determine the base and shaft area in the two papers?

The failure of the pile side may occur along the interface between pile and soil or in the soils around pile. Therefore, the full flight diameter $D_{\mathrm{f}}$ may be used to determine the shaft area. As to the calculation of the base capacity, the full flight diameter $D_{\mathrm{f}}$ may also be selected to calculate the base area. In the paper of Jeffrey et al. (2016), the calculated result tends to under-predict the measured pile capacity by an average of $25 \%$ at higher relative densities. This may due to the fact that the full flight diameter $D_{\mathrm{f}}$ and the effective diameter $D_{\mathrm{e}}$ are used to calculate the base and the shaft area, respectively. When the full flight diameter $D_{\mathrm{f}}$ is used to calculate the base area and the shaft area, the calculated shaft and bearing capacity may be well consistent with the measured result.

\section{Authors' reply}

The authors would like to thank Professors Cui and Zhang and colleagues for their interest in this work on understanding the performance of continuous helical displacement piles (CHD), a type of cast-in-situ auger displacement pile developed in the UK. Raising this discussion has indicated that it would be beneficial to clarify the points raised, so that any apparent confusion in the original paper can be clarified and to confirm that the approach adopted in Knappett et al. (2016) is consistent with the findings and recommendations in Jeffrey et al. (2016).

The authors would like to clarify that in Section 4 of Jeffrey et al. (2016) the text initially refers to the approach used in practice for the design of CHD piles prior to undertaking this research, where it has been normal to calculate the pile shaft contribution to the pile's resistance using an effective diameter $\left(D_{\mathrm{e}}\right)$, which has typically been taken as $0 \cdot 75 D_{\mathrm{f}}$ (where $D_{\mathrm{f}}$ is the outer flight diameter for an auger displacement pile). This approach was recognised as conservative when compared with other approaches adopted in Europe - for example, van Impe (2004) recommends that $D_{\mathrm{e}}=D_{\mathrm{f}}$ and Bustamante and Gianeselli (1993) propose adopting a value of $D_{\mathrm{e}}=0 \cdot 9 D_{\mathrm{f}}$ (see also Section 1 in the original paper). These differences in approach provided one of the original motivations for undertaking the research described in Jeffrey et al. (2016) and Knappett et al. (2016).

In Sections 4 and 5 of Jeffrey et al. (2016) it is recommended that the contribution of the pile base (Equation 1) is calculated using an area based upon the pile core diameter $\left(D_{\mathrm{c}}\right)$ rather than $D_{\mathrm{f}}$. This approach was recommended based upon the results shown in Figure 13, where a back-calculated base bearing capacity factor $\left(N_{\mathrm{q}}\right)$ showed much better correlation with the work of Berezantzev et al. (1961) when core diameter $\left(D_{\mathrm{c}}\right)$ rather than flight diameter $\left(D_{\mathrm{f}}\right)$ was used (Figure 13(b) in the original paper). This is consistent with the shape of the CHD pile, which tapers from $D_{\mathrm{c}}$ below the lowest flight to a point at the base of the pile, explaining why this gives a better correlation for this pile type. This is consistent with Equation 5 in Knappett et al. (2016).

When considering the shaft contribution, the full flight diameter $D_{\mathrm{f}}$ was used, initially based upon the observations of the 
exhumed model piles where the sand was tightly packed between the flights of the pile and the exhumed pile resembled a straight shafted pile of diameter $D_{\mathrm{f}}$ with a sand-sand shear surface (Figure 7). Second, when comparing the CHD piles with jacked piles of diameters equivalent to the core or flight diameter of the CHD it was found that the results for a jacked pile with base diameter $D_{\mathrm{f}}$ were far closer in capacity than those for $D_{\mathrm{c}}$ (Figure 6).

The determination of the earth pressure coefficient, $K$, in Figure 14 was based upon the use of $D_{\mathrm{f}}$ rather than $D_{\mathrm{c}}$, as this represents the diameter along the shaft of both CHD and jacked piles and is consistent with the approaches of Bell (2010), Meyerhof (1976) and Mitsch and Clemence (1985). This is also consistent with Equation 3 in Knappett et al. (2016). Therefore, the under-prediction noted is not as a result of the approach adopted with respect to diameter selection for the various contributions to pile capacity, but is more likely to be due to the method proposed for determination of the earth pressure coefficient (Equation 2, Figure 14). Based upon the results shown in Figure 14 it is clear that there is greater scatter in the data with increasing peak friction angle (or relative density). Based upon this scatter and the large peak friction angles experienced at small scale and low stress levels in the laboratory (Lauder and Brown, 2014) that are unlikely to be encountered in the field (at full scale) it was decided to adopt the Mitsch and Clemence (1985) approach (Figure 14, Equation 4). This approach represents a lower bound to $K$ at higher friction angles (laboratory scale), but is a better representation of displacement pile behaviour at lower friction angles (field scale) and is thus a more appropriate recommendation for adoption in design practice.

\section{REFERENCES}

Bell A (2010) Foundation solutions for the urban regeneration of Glasgow city centre. In Proceedings of the DFI and EFFC 11th International Conference: Geotechnical Challenges in Urban Regeneration, London, UK. EMAP Networks, Peterborough, UK, pp. 120-129.

Berezantzev VG, Khristoforov VS and Golubkov VN (1961) Load bearing capacity and deformation of piled foundations. Proceedings of the 5th International Conference on Soil Mechanics and Foundations Engineering, Paris, France, pp. 11-15.

Bustamante M and Gianeselli L (1993) Design of auger displacement piles from in situ tests. In Proceedings of the 2nd International Geotechnical Seminar on Deep Foundations on Bored and Auger Piles, BAP II, Ghent, Belgium (van Impe WF (ed.)). Balkema, Rotterdam, the Netherlands, pp. 21-34.

Jeffrey JR, Brown MJ, Knappett JA, Ball JD and Caucis K (2016) CHD pile performance: part I - physical modelling. Proceedings of the Institution of Civil Engineers - Geotechnical Engineering 169(5): 421-435, http://dx.doi.org/10.1680/jgeen.15.00131.

Knappett JA, Caucis K, Brown MJ, Jeffrey JR and Ball JD (2016) CHD pile performance: part II - numerical modelling. Proceedings of the Institution of Civil Engineers - Geotechnical Engineering 169(5): 436-454, http://dx.doi.org/10.1680/ jgeen.15.00132.

Lauder K and Brown MJ (2014) Scaling effects in the 1g modelling of offshore pipeline ploughs. In Proceedings of the 8th International Conference on Physical Modelling in Geotechnics, Perth, Western Australia (Gaudin C and White D (eds)). CRC Press, Boca Raton, FL, USA, pp. 377-383.

Mitsch MP and Clemence SP (1985) The uplift capacity of helix anchors in sand. Uplift Behavior of Anchor Foundations in Soil, Proceedings of a Session held in conjunction with the ASCE Convention, Detroit, MI, USA, pp. 26-47.

Meyerhof GG (1976) Bearing capacity and settlement of pile foundations. ASCE Journal of the Geotechnical Engineering Division 102(GT3): 197-228.

van Impe WF (2004) The Overview of Almost Two Decades of Full Scale Research on Screw Piles. Laboratory of Soil Mechanics, Ghent University, Ghent, Belgium. 